\title{
Constitutionalism as Protector or Disrupter of Nationalism: A Selected Central, Eastern European and Eurasian Review
}

\section{David M. Kirkham *}

The past decade has witnessed a proliferation of constitution making throughout the world. The widespread fall or transmutation of authoritarian regimes and the general disenchantment with communist ideology left democracy in all its forms, at least for the time being, as the only viable political ideology and system of government standing. The consequent worldwide surge towards democracy brought with it a natural, necessary, and enthusiastic penchant for constitution making.

This is quite understandable, if not entirely logical. Constitutions naturally accompany democratic governments, although not all democratic governments, including the United Kingdom and Israel, have written constitutions. Still, the fact that most democratic governments exist under written constitutions has led to the international community adopting, for all intents and purposes, the notion that any new state striving-or any old state newly claiming - to be democratic, must indeed have a written constitution. Experience has shown, however, that a constitution alone does not make a democracy. To sustain a healthy democracy, the key lies not just in adopting a constitution, but in adopting constitutionalism - a way of thought or set of cultural norms that widely recognizes legal, enforceable protections of democratic culture and its institutions. Democracy and constitutionalism are similar but not synonymous, and the mere existence of a constitution does not necessarily guarantee either.

Students of government are generally aware that there is more to liberal constitutionalism than a written basic law charter. Constitutionalism can only exist over the long term in a society that has adopted a constitutional culture. That means a culture in which all members of the society-including government, the press, and citizens at large - understand, accept, and work to protect the basic principles of constitutionalism, i.e., limited government, the rule of law, and the guarantee of fundamental individual freedoms.

The motivation behind making new constitutions almost always includes a desire to foster constitutionalism. It is not the sole motivation for making a constitution, however. There are the pragmatic motives, for example, of the non-idealists, who simply seek international recognition and membership in those organizations that promise protection and prosperity, such as NATO and the EU. A still more important motive for some constitution-makers, however, is the desire to codify and receive recognition for a putative national identity. Ethnic groups or nations that are extremely proud of their historical and cultural identity or who have suffered for their ethnicity are especially likely to seek to bring about national unity and international endorsement and protection for them as a group. They may wish to sustain those national, religious, or ideological values that have served them well and that speak to what they most pro-

David M. Kirkham is Professor of International Politics and Democratic Studies, George C. Marshall European Center for Security Studies. 
foundly believe themselves to be. It short, they seek to engage their constitution in the service of nationalism.

This may or may not work. Constitutionalism and nationalism may make nice bedfellows, or they may be split asunder by incompatible differences. Constitutionalism can either sustain and protect or disrupt and interfere with nationalistic tendencies in a society. Many written constitutions attempt to preserve elements of a national identity. They decree, for example, an official language, a dominant religion, and so on, in order to promote national unity and stability. However, when minority and individual rights are threatened as a result of nationalistic behaviors, constitutional principles may demand a compromise from nationalists, or the abandonment of some traditional nationalistic practices altogether.

How far a constitution goes in preserving or disrupting nationalism is always a balancing act. The plethora of new constitutions to come on the world scene in the last decade or so reveals the variety of ways in which constitution-makers have attempted to achieve an appropriate balance. Where the two notions collide, however, constitutionalism will either trump nationalism, or else cease to exist. Therefore, the presumption among constitution-makers who are sincerely trying to build a democracy is that nationalism should take a back seat to constitutionalism. In cases where nationalistic constitution makers are merely wooing world approval by adopting a constitution pro forma under the guise of democratic reform, they may actually assume the contrary.

Not all nationalists, however, are evil xenophobic provincials determined to protect their own interests, regardless of the cost to others. However discredited nationalism has become as a result of the Second World War and the ethnic conflicts that have plagued the world since then, there remain, as always, many benign motives for wanting to sustain a national identity. In the present moment, where many see globalization as a threat to a way of life that they have come to cherish, a people may be inclined to work hard-and not necessarily at the expense of others - to protect those values that have served them well. The presumption in favor of constitutionalism, therefore, has caused nationalist constitution-makers to make greater efforts to define and protect national identity in the constitution itself. Such efforts range from statements of intent in constitutional preambles to binding provisions within the normative text of the constitution.

An examination of the constitutions adopted since 1990 in Eastern and Central Europe and Eurasia reveals framers' attempts in many cases to preserve a national identity while still protecting minority rights. Some states appear to be enjoying more success in this balancing act than others.

The bulk of the remainder of this article will sample four "new" constitutions from the region ranging from Eastern Europe to Central Asia in an examination of the language they use to protect or promote the national identity or identities of the country in question. In presenting these four examples - from the Republic of Macedonia, Poland, Uzbekistan, and Russia - this work asserts no particular expertise in the traditions of constitutional history, constitutional law, or constitutional interpretation in these countries. This study represents only the very modest beginnings of an exploration of the relationship between constitutionalism and nationalism in the region. The focus here 
will be primarily (though not solely) on the language of the documents, drawn from reliable English translations of these constitutions, all the time recognizing that language cannot stand alone outside of its historical, political, and legal context.

Though no claim is made that they are completely representative of the region, the four countries in this initial study have not been chosen entirely at random either. They geographically cover the four corners of the region in question and represent nations of various sizes, levels of political stability, economic strength, and at different stages of democratic development. Each has adopted a new constitution since 1991. The selection is random only in the sense that they have not been chosen as a result of any particularly interesting language, either for or against nationalism, in their constitutions. In fact, their constitutions themselves were not examined until after the selection was made.

\section{Nationalistic Language and Constitutional Preambles}

It could be said that constitutions, by definition, are nationalistic (though not necessarily ethnocentric). They intend to create and unify a nation - to elucidate that which constitutes the nation state, to in effect write a nation into being. Most constitutions intending to protect or promote a particular national identity place the strongest nationalistic language in their preamble. This placement both strengthens and weakens the argument that the authors of the constitution took the protection of national identity seriously. Preambles play a particular role in a constitution. As noted among proponents of a new preamble for an Australian republican constitution, "Preambles serve to set out the context of a Constitution and often to assert basic principles of the society. Every constitution [of those having preambles] has a different preamble, and they range from florid and poetic to functional and legalistic." " Preambles generally are more intended as statements of purpose and less intended to make law. According to George Winterton, Professor of Law at the University of New South Wales, "The constitutional preambles of many nations declare commitment to fundamental constitutional principles, such as democratic government and equality before the law, and to core civic values or aspirations, such as justice, fraternity and world peace." ${ }^{2}$

Placing pro-national language in the preamble strengthens its importance because, by listing the provisions of national identity up front, it gives them the symbolic weight of being among the most fundamental objectives of the constitution-in fact, they come to be seen as the very purpose for which the constitution exists. On the other hand, the language in preambles is generally of limited legal effect. It usually contributes more towards interpretation of the document than towards creating binding normative terms. Regarding the constitution of the United States, for instance, "no court

1 “Constitutions Compared: Constitutional Preambles," available at http://www.abc.net.au/ concon/compare/preamble/pream.htm, last accessed 2 July 2004.

2 "Reconciliation and Social Justice Library," available at http://www.austlii.edu.au/au/ other/IndigLRes/car/1997/3/book4/Pages/04cp02.htm, last accessed 6 July 2004. 
has ever held that the Preamble independently grants power to the government or to any of its officers or agencies." In fact, there is precedent for the contrary view. ${ }^{3}$

Not all constitutions include extensive preambles. For example, before proceeding with the substance of the document, the Latvian Constitution begins simply: "The people of Latvia, in freely elected Constitutional Assembly, have adopted the following State Constitution." And, on its face, this constitution is not strongly nationalistic. It does provide some protections for Latvia's national identity, however, particularly in the form of proclaiming Latvian as the national language, which is a fundamental cultural determinant whose importance cannot be sufficiently stressed. ${ }^{4}$

\section{The Constitution of the Former Yugoslav Republic of Macedonia}

Citizens of the Republic of Macedonia see themselves with some pride as belonging to an ancient race whose glory days hearken back to the reigns of King Philip II (r. 359336 BCE) and Alexander the Great (r. 336-323 BCE). Macedonians today sometimes trace their constitutional history all the way back to Philip, but more often to the shortlived Khrushevo Republic of 1903 (suppressed by the Ottomans) and to the later Macedonian Republic that emerged from the Second World War as part of Yugoslavia. With the fall of Communism in Eastern Europe, Macedonia declared independence in 1991 and reconstituted itself with the new Macedonian Constitution that went into effect on November 20 of that year. There was some controversy over Macedonian national identity right from the beginning, with Greece claiming the name Macedonia as Hellenic and applying to a region of its domain. The present Republic found an interim solution with Greece in adopting the name, at least for now, "The Former Yugoslav Republic of Macedonia" (or, more commonly, FYROM). ${ }^{5}$

The 1991 constitution (and as amended in 2001) takes as its "points of departure the historical, cultural, spiritual and statehood heritage of the Macedonian people." The country's inhabitants are about 64 percent ethnic Macedonians and 25 percent Albanian, with no other group statistically dominant. Though the constitution is well grounded in democratic provisions, the preamble describes a multi-cultural citizenry, distinguishing between the "Macedonian" people and "Albanians, Turks, Vlachs, Romanics and other nationalities living in the Republic of Macedonia." This distinction arose as much at the instigation of the minorities mentioned, who were seeking to preserve their identity, as from demands by ethnic Macedonians. Conflicts, especially between Macedonians and Albanians, have been common in recent years until, "in No-

3 Dennis J. Mahoney, "Preamble," in The Encyclopedia of the American Constitution, eds. Leonard W. Levy, et al. (New York: Macmillan Publishing Co., 1986), 1436.

4 "Latvian Constitution," available at http://www.saeima.lv/LapasEnglish/Constitution Visa.htm, last accessed 30 June 2004.

5 "Russian News Network: Former Yugoslav Republic of Macedonia," available at http://www.russiannewsnetwork.com/europe/macedonia.html, last accessed 2 July 2004. "History of Macedonia," available at http://www.macedonia.com/english/history/, last accessed 9 July 2004. "History of Macedonia.org," available at http://historyof macedonia.org/, last accessed 9 July 2004. 
vember of 2001, the Macedonian Assembly approved a series of new constitutional amendments strengthening minority rights." ${ }^{6}$

The preamble hearkens back to historic moments of national pride during the Krushevo Republic and "the historic decisions of the Anti-Fascist Assembly of the People's Liberation of Macedonia." It describes its intent as, among other things, the "provision of peace and a common home for the Macedonian people with the nationalities living in the Republic of Macedonia," again a form of separate-but-equal clause. $^{7}$

Article 7 of the substantive provisions of the constitution states, "The Macedonian language, written using its Cyrillic alphabet, is the official language in the Republic of Macedonia," while allowing for possible second or third official languages in those regions where a "nationality" constitutes the majority. The intent here can be read either as an ethnocentric attempt to establish Macedonian as the dominant tongue or, viewed more benignly, as establishing some degree of national unity through the use of one primary official language. Article 19 allows for religious freedom, the final provision being rather oddly worded, however, in singling out "the Macedonian Orthodox Church" from "other religious communities and groups," all of which are nonetheless "free to establish schools and other social and charitable institutions." This separate mention of the Orthodox Church makes sense only if it is seen as intending in some way to preserve a preference for a clearly national institution. ${ }^{8}$ Article 36 guarantees "particular social security rights to," among others, "those expelled and imprisoned for the ideas of the separate identity of the Macedonian people and of Macedonian statehood." $"$

These examples suffice for an article of this length to illustrate some latent (if not patent) nationalism in the Macedonian Constitution. It must be said that the Macedonian Constitution is rife with provisions guaranteeing basic human rights and civil liberties, and special provisions exist to resolve ethnic concerns at every turn. The document nonetheless clearly attempts to maintain a Macedonian identity without infringing on the rights of others. Whether the results of minority ethnic groups fearing that their own identities would be swallowed up in a larger national identity or of a Macedonian majority asserting its dominance, the constitution clearly attempts to strike a balance between protecting these separate identities and creating a unified nation. As such, it does not resolve the tensions that will likely continue to occur between these various "nationalities" but, for the moment, neither does it aggravate them.

6 "Republic of Macedonia: Constitution," available at http://www.b-info.com/places/ Macedonia/republic/Constitution.shtml, last accessed 9 July 2004. CIA World Factbook, "The Former Yugoslav Republic of Macedonia," available at http://www.odci.gov/cia/ publications/factbook/print/mk.html, last accessed 2 July 2004.

7 "Republic of Macedonia: Constitution."

8 Ibid.

9 Ibid. 


\section{The Republic of Poland}

The strongly democratic constitution of modern Poland was established by national referendum in May 1997. Unlike Macedonia, with its high level of ethnic diversity, Poland is 98 percent ethnic Polish, the most homogeneous of the four countries reviewed here. One might surmise, then, that it would be easier for the Polish Constitution to protect or provide for a national identity. ${ }^{10}$

The constitution of the Republic of Poland is in fact strongly nationalistic as well as liberally democratic. Polish historical sensitivities are revealed in the very first line: "Having regard for the existence and future of our Homeland...." Those propounding the constitution are first "We, the Polish Nation," and only second, "citizens of the Republic." Still in the preamble, the common good is defined as "Poland," and the framers note their obligation "to bequeath to future generations all that is valuable from our over one thousand years' heritage," a strong statement of historical identity. Not only does this delineation of national identity cut across time for its roots, but, recognizing Poles as "bound in community with our compatriots dispersed throughout the world," it reaches also across space to the Polish diaspora. Substantive provisions take this a step further with Article 6(2), which requires that "the Republic of Poland shall provide assistance to Poles living abroad to maintain their links with the national cultural heritage."

Religion and language are key components of national identity. Poland is a strongly Roman Catholic country, and the preamble makes clear that the nation's Christian heritage is not to be ignored in public debate. It does, however, protect the interests of those Poles who prefer a secular approach to their politics: the constituents include "both those who believe in God as the source of truth, justice, good and beauty, as well as those not sharing such faith but respecting those universal values as arising from other sources," and they recognize a "culture rooted in the Christian heritage of the Nation and in universal human values." The Roman Catholic Church is given special mention in the substance of the document but with the apparent intent of clarifying its separation from the state, rather than marrying the two. Article 25 provides for the equality of religions, and then states, "the relations between the Republic of Poland and the Roman Catholic Church shall be determined by international treaty concluded with the Holy See, and by statute."

As for linguistic rights, Article 27 provides that Polish will be the nation's official language, but promises that "this provision shall not infringe upon national minority rights resulting from ratified international agreements." Article 5 agrees to "safeguard" Poland's "national heritage," and Article 6 unabashedly states that the Republic "shall

10 “U.S. Department of State Background Note: Poland," available at http://www.state.gov/r/pa/ ei/bgn/2875.htm, last accessed on 22 June 2004. Polish Constitution, 6 October 1997; adopted by the National Assembly 2 April 1997; passed by national referendum 23 May 1997. CIA World Factbook, "Poland," available at http://www.odci.gov/cia/publications/ factbook/print/pl.html. 
provide conditions for the people's equal access to cultural goods which are the source of the Nation's identity, continuity and development."

The rights of minorities to their own ethnic identities are clearly protected in the Polish Constitution. Article 35 reads:

(1) The Republic of Poland shall ensure Polish citizens belonging to national or ethnic minorities the freedom to maintain and develop their own language, to maintain customs and traditions, and to develop their own culture.

(2) National and ethnic minorities shall have the right to establish educational and cultural institutions, institutions designed to protect religious identity, as well as to participate in the resolution of matters connected with their cultural identity. ${ }^{11}$

Poland, with its homogenous culture and its troubled yet proud past, having historic precedents for republican government and yet so often torn by aggressors on either side, has produced a constitution that is not only liberal and democratic, infused with checks and balances and upholding the rule of law, but that likewise provides strongly for the preservation of the national identity of the Polish people.

\section{The Republic of Uzbekistan}

Of the four states whose constitutions are featured here, Uzbekistan has likely traveled the shortest distance on the road to liberal constitutionalism-Russia notwithstanding. This case provides at least one opportunity to examine the relationships between nationalism and illiberal governments. Uzbekistan's constitution, adopted on 8 December 1992, contains plenty of "rule of law"-type provisions, but the political realities do not reflect the words in the constitution, and President Karimov is generally seen as an autocratic leader who has given democracy short shrift.

The population of Uzbekistan is 80 percent Uzbek and 20 percent various minorities. ${ }^{12}$ Unlike Poland, which has a strong nationalistic tint to its preamble, the preamble of Uzbekistan's constitution is nearly devoid of nationalistic language. It does, however, pay powerful homage to democracy. The preamble reads:

The People of Uzbekistan, solemnly declaring our devotion to human rights and the principles of state sovereignty, understanding a high responsibility before present and future generations, relying on the historical experience of the development of the Uzbek state, affirming our fidelity to the ideals of democracy and social justice, recognizing the primacy of generally recognized norms of international law, endeavoring to ensure a worthy life to citizens of the republic, setting as a goal the formation of a humanitarian democratic state operating under the rule of law, and in order to

11 "Poland - Constitution," available at http://www.oefre.unibe.ch/law/icl/pl00000_.html, last accessed 21 June 2004.

12 "U.S. Department of State Background Note: Uzbekistan," available at http://www.state.gov/ r/pa/ei/bgn/2924.htm, last accessed on 5 July 2004. 
ensure civic peace and national accord through our authorized representatives adopt this Constitution of the Republic of Uzbekistan. ${ }^{13}$

The normative articles declare Uzbek the country's official language, but also ensure "a respectful attitude towards the languages, customs, and traditions of the nationalities and peoples living on its territory and ensures conditions for their development." One of the requirements for the presidency is that one have fluent command of the state language, but this can be read as much as a practical matter as a nationalistic principle.

Freedom of religion is guaranteed, but particular religions are not mentioned - not even Islam, in a country that is 88 percent Sunni Muslim. Other than protection of Karakalpakstan's autonomy, including dual nationality for Karakalpak citizens, ethnic groups or nationalities are at no point singled out by name; rather, emphasis is placed on the unity of legal status: "A single citizenship is established in the Republic of Uzbekistan for the entire territory of the republic." Article 57 prohibits ethnically- or religiously-based political parties. ${ }^{14}$

In the end, then, the Constitution of the Republic of Uzbekistan is remarkably lacking in nationalistic language and provisions. It is strongly characterized by the language of democracy and liberal institutions, though the country of Uzbekistan is not generally recognized as a liberal democracy. Although autocracies often thrive where nationalism is strongest (e.g., Hitler's Third Reich, Japan's Empire of the Rising Sun, Milosevic's Serbia), the Soviet legacy is less nationalistic, and may account for some of Uzbekistan's present particularities. This is not to say that Uzbekistan is not nationalistic, or that President Karimov never makes appeals to nationalism to consolidate his rule. These questions, too, fall outside the scope of this essay. It is only to reinforce the fact that the absence of nationalism in a constitutional charter-comparing Uzbekistan to Poland, for example - is not evidence that liberal constitutionalism is stronger in that country.

\section{The Russian Federation}

The history of Russia requires no extensive review in this article. The country is ethnically 81 percent Russian. None of the minorities composing the remaining 19 percent is significantly more numerous than the others. Following months of great political unrest, the present constitution of Russia was ratified on 12 December 1993. Contrary to Poland's basic charter, Russia's constitution declares itself, at the very outset, to be the product of a "multinational people ... united by a common destiny on our land." The entire preamble merits citation here:

We, the multinational people of the Russian Federation, united by a common destiny on our land, asserting human rights and liberties, civil peace and accord, preserving the historic unity of the state, proceeding from the commonly recognized principles

13 "Constitution of the Republic of Uzbekistan," available at http://www.ecostan.org/laws/uzb/ uzbekistancon_eng.html, last accessed 2 July 2004.

14 CIA World Factbook, "Uzbekistan," available at http://www.odci.gov/cia/publications/ factbook/print/uz.html; "Constitution of the Republic of Uzbekistan." 
of equality and self-determination of the peoples honoring the memory of our ancestors, who have passed on to us love of and respect for our homeland and faith in good and justice, reviving the sovereign statehood of Russia and asserting its immutable democratic foundations, striving to secure the wellbeing and prosperity of Russia and proceeding from a sense of responsibility for our homeland before the present and future generations, and being aware of ourselves as part of the world community, hereby approve the Constitution of the Russian Federation. ${ }^{15}$

References to "historic unity," "honoring the memory" of ancestors, and love for homeland are all arguably nationalistic in nature, but not such as to elevate or even distinguish ethnic Russians or any other national group from one another. The unique turn of phrase here, "being aware of ourselves as part of the world community" - both pays homage to Russia's traditional status as a world power and, more benignly, steers the country clear of too strong a nationalistic identity.

In reaction to the Communist era, the constitution establishes "ideological plurality" as well as religious freedom. Though rights to "participation in cultural life, to the use of institutions of culture, and access to cultural values" are guaranteed, no context is provided that would suggest the superiority of "Russian values." The constitution does, however, demand that everyone "care for the preservation of the historic and cultural heritage and safeguard landmarks of history and culture." Article 68 declares Russian to be the state language of the Russian Federation, but allows the various republics to establish their own state language to be used alongside Russian, if they so desire. Article 69 guarantees the rights of minority "indigenous peoples."

In the end, the Russian Constitution is not strongly nationalistic. It recognizes the nation's place in the world community and places no particular emphasis on ethnic history, tradition, or values. The Russian Constitution is one of the longest here examined, making nationalistic references all the more rare relative to its overall length. The theme of the constitution, however much followed in practice or honored in the breach, is one of united diversity. The Russian Constitution, as is the case in the other three constitutions examined here, appears to establish democratic government and the rule of law. It is well known that President Putin wields considerable power, and where Russia ultimately settles along the democratic continuum remains to be seen, but this too exceeds the scope of analysis here.

\section{Conclusion}

Any conclusions drawn here must remain tentative. As noted at the beginning, this article represents just the beginning of a larger examination of this subject. But what initial inferences might be drawn from the data here? First of all, there is no particular corre-

15 "U.S. Department of State Background Note: Russia," available at http://www.state.gov/ r/pa/ei/bgn/3183.htm. CIA World Factbook, "Russia," available at http://www.odci.gov/cia/ publications/factbook/print/rs.html, last accessed 2 July 2004. "The Constitution of the Russian Federation," available at http://www.departments.bucknell.edu/russian/const/constit. html, last accessed 9 July 2004.

16 "The Constitution of the Russian Federation." 
spondence between the presence of cultural constitutionalism (or cultural liberal democracy) in a country and the promotion of nationalism in the constitution. The most nationalistic constitution of the four here examined comes from Poland, and yet Poland is probably the most democratic culturally. The least nationalistic of the four constitutions comes from Uzbekistan, yet as a nation, Uzbekistan is also the least characterized by constitutionalism or democracy. Historically, however, autocracies have been known to thrive in nationalistic cultures. We might say at this stage that, if national values include honoring the rule of law, then nationalism is a positive thing, one that is very desirable for constitutions. If a state's traditional national identity spurns democracy, however, then the less nationalism present in that state's constitution, the more the constitution can help facilitate cultural change. In the case of Uzbekistan, the general tone of the constitution may be exactly what is needed - that is, if it is not allowed to persist so long under autocratic conditions so as to make cynics of the people regarding democracy.

In most cases the constitutions examined here are too young for a definitive statement to be made about how tensions between nationalism and the ideals of the rule of law can be resolved constitutionally. Different countries have different mechanisms for reconciling these tensions. In the end, however, how these tensions are resolved over time will determine if the nations of the region will adopt the kinds of flexible constitutional cultures - constitutionalism, if you will - needed to move forward in concert with the democratic nations of the world, or whether these nations will isolate themselves as nationalistic entities, oppressive to their resident minorities, and potentially threatening to international security. 
VOL. III, NO. 4, DECEMBER 2004

\section{Bibliography}

Mahoney, Dennis J.. Preamble In The Encyclopedia of the American Constitution. New York: Macmillan Publishing Co, 1986. 